\title{
The Impact of Coastal Urban Logistics Economic Development on International Trade Development
}

\author{
DongXiaoYu
}

Hainan College of Economics and Business, 571127, China

Keywords: Logistics economy; International trade development; Coastal city; Influence

\begin{abstract}
With the continuous development of economic globalization, international economic and trade activities are becoming more and more frequent, and the scope of Chinese economic activities is also expanding. China's coastal urban economic development continues to deepen under the impetus of reform and opening up economic special zones construction, and coastal economic open belt is formed. Logistics economic development is an important area of China's economic and trade, and coastal logistics economic development is obvious in geographical advantage, and it closely interacts with international trade. The impact of coastal city logistics economic development on the development of international trade has been deepened. The impact of coastal city logistics economic development on international trade is analyzed in this paper to provide theoretical support for the internationalization of logistics economy.
\end{abstract}

Since ancient times, the development of coastal cities has geographical advantage. The opening of Silk Road on the sea and the historical development of coastal ports open up a new space for coastal economic development. Since the reform and opening up, the establishment of special economic zones provides an empirical basis for coastal open city development. In an open economic environment, new development elements continue to emerge, providing more conditions for open economic development. Coastal city economy continues to deepen in the process of reform and opening up which provides an empirical basis for China's economic development. In open economic environment, the establishment of international trade and closer exchanges are important conditions for deepening economic development. In recent years, "The Belt and Road" and friendly exchanges in inter-country trade are more and more influential in the development of international trade. Under open economy, the rise of logistics is the product of the development of the times. It is with great potential and it has a catalytic role in the development of local economy and the construction of coastal economic zones. Logistics becomes a new economic growth point in China's coastal cities enterprises development. Transportation, storage facilities, information and communication, cargo packaging and handling infrastructure development have a certain scale, and they have certain material basis in the development of logistics industry. The development of regional logistics economy has geography characteristics. The available resources and conditions are important factors. China's coastal logistics and economic development is still in the process of continuous improvement. In global economic development environment, the deepening of logistics economy development will have a more far-reaching impact on international trade development.

\section{China's coastal city logistics economy development status analysis}

China's coastal cities relying on port advantages have more advantages in economic development. In recent years, the position of logistics economy is increasingly prominent in China's economic development. The development of port logistics has an important role in promoting national infrastructure construction, industrialization process, and foreign economic development. The rise and development of coastal logistics is deepening, reducing transportation cost and transaction cost of economic development, and it promotes regional economic growth under industrial agglomeration effect. Although logistics has a broad space for development, the current problems in logistics industry development is still the important issue in economic development, such as low efficiency, logistics talent shortage, management backward, business model and social 
development gap, and so on. In the fierce national market development, the development and competition of logistics economic will be more intense. [1]

The development of modern logistics industry has been paid attention to, and the total cost has been increasing. The progress of logistics infrastructure and information construction has been accelerating, and supply chain management has accelerated the development trend. The overall development of logistics agglomeration areas has been continuously regionalized and industrialized. Logistics enterprises grow in the strength, and market concentration has been significantly improved. Integration, mergers and acquisitions, and reorganization continue to expand in logistics enterprises at home and abroad, which makes the rapid development of logistics enterprises. In geographical advantage, make full use of location advantages, accurately locate the direction of local economic development, accelerate economic development of coastal areas, and give full play to coastal geographical advantages. These are of great significance in coastal open economy strategic development. Coastal cities have an important impact on coastal economic and social development in the development of logistics industry. With the support of national policies, the vigorous development of regional economic has important material support for international trade.

Coastal city logistics and economic development is facing more problems and challenges. At the same time when logistics needs increase with increased competition, logistics factors appear shortage situation, and logistics industry average profit rate further declines. The development of third-party logistics is subject to institutional constraints, government restrictions, policy ambiguity and the lack of high-quality personnel in China's domestic logistics enterprises and international logistics enterprises. Institutional constraints are not fundamentally solved, which has a very negative impact on the development of logistics industry. At the same time the high cost proportion in GDP share never goes down in the development of logistics industry, which reflects that China's economy is in the transition period from extensive business to intensive management. The overall level of information technology of logistics industry is low, and the application of modern information technology and network technology in logistics industry has not yet been comprehensively developed, which cannot meet the needs of logistics services and lack of information systems support. Imperfect enterprise information systems have a hindrance to enterprises operation. Modern information technology has no technical support in logistics industry application, which is an urgent problem to be solved. [2]

The development of China's coastal city logistics is in development period, but in economic development and demand saturation environment, many resource conditions will be affected. In operating mode and advanced personnel training, development problems are of great inspiration at this stage personnel training and introduction. The advantages of coastal cities in economic development is significant, and international market compatible conditions will have higher requirements for the introduction of professional talents, which improves the level of logistics economy development in international trade and strengthen regional economic development exchanges. The elasticity demand for logistics increases year by year, and the contribution of logistics in economic growth is increasing. The internationalization process is accelerating, and industrial planning and construction has been gradually improved. The development of information industry has been accelerating. State macroeconomic policy regulation, the development of national economy, the geographical development of logistics industry in coastal economic zone is the general trends of international logistics development. China's coastal urban economic development rose gradually after reform and opening up, and the developing time is short. There are still a lot of imperfect problems in social development experience and planning. Therefore, the development of logistics economy has no enough experience in the development of new industries. The problems in the development are becoming more and more complicated. In international trade background, logistics economics development also needs more deepening.

\section{The impact of coastal urban logistics economic development on the development of international trade}

Coastal city logistics and economic development has an important impact on the development 
of international trade. In the process of deepening economic development and continuously upgrading industrial structure, the development of coastal city logistics economy promotes the establishment of international trade system, and coastal economic belt development depends on the advantages of maritime transport communication in trade development between countries and regions. Logistics costs and logistics value ever changes in logistics economy. The development needs to go through a process. The system gradually established in international trade, relying on regional economic organizations' increasing communication opportunities, is constantly improved, form certain trade rules, and is conducive to the stable development of international trade.

Internal adjustment of international trade changes with continuous development of coastal city logistics economy, and the demand for the development of the times is changing. The promotion of human production and life is also advancing social and economic development and social progress. The new elements of logistics economy continue to appear. In ever-changing information age, the development of logistics industry will meet the needs of the people, and at the same time is under socio-economic impact. It escalates in overall industrial adjustment and international trade development will be adjusted to it. Regional economy impact on national economy is not decisive, but the impact on international pattern cannot be underestimated. International trade is a macro concept, but the influence of logistics economy is increasingly larger, which will also affect the internal structure of international trade and change traditional structure.

Under the development trend of regional economic integration, coastal city logistics economy has an important influence on the deepening of international trade. The development of international economic and trade is mainly manifested in international economic integration, financial crisis and regional economic development restriction, which will affect the development of international trade. Under the environment, logistics economy in China's coastal cities is more vulnerable to financial crisis and economic constraints influence. From the restrictive factors of previous economic development, the strengthening of coastal logistics economy development has an important role in promoting the deepening of national trade development. Trades between countries need to reach a certain understanding, and under the conditions of smooth trade channels, logistics economic development can have more space.

In regional development of coastal logistics economy, the overall development of port group is planned, and the logistics development in China's Bo Sea port, southeast coastal port, southwest coastal port, Yangtze River Delta port and Pearl River Delta port is reasonably planned under different industrial structures. The overall development of several major port groups in the development of differentiated development can reduce ineffective competition and improve the overall port group logistics development level. In ports development, international trade development is mostly developed by port advantage. In world's important ports, the use of favorable conditions for the development of international trade is more and more common, so we should make reasonable and scientific development in the integration planning of port group and the optimization of industrial structure. Industrial structure affects the level of development of regional logistics economy, giving full play to the overall advantages of ports. Strengthen cooperation between the ports and ensure the level of development in logistics services. In industrial construction, the support and leading of high-tech industry promotes port logistics development and ensures the development level of port logistics. [3]

Coastal city economic development gradually develops into scale because of the support of government policy. The development of logistics economy is in the prosperous period of economic development in coastal areas, and the development of logistics enterprises happens in a relatively stable market environment, but it is also faced with certain challenges. National policy support is an important measure to promote enterprises economic progress. National administrative departments should play administrative functions to give more attention to the development of coastal logistics, provide policy support to coastal ports whose logistics development is at a lower level, increase policy support and overall planning, and promote the development of coastal city logistics economy through policies. [4]

The development of new industries requires more development experience, while the training of 
personnel also needs more exploration practice. The development of coastal logistics economy can learn from the experience of other industrial economic development. On the basis of drawing on advanced management development and operation experience, enhance international communication and exchange experience, learn from the experience of foreign logistics, and make continuous improvement in localization. With the actual development situation, explore important development path which is suitable for China's coastal city logistics. In talents training, the cultivation of talents in colleges and universities in our country has been preceded by the establishment of professional talents. It has formed a certain theoretical basis for personnel training in logistics related fields. In the exchange of talents, we can promote international cooperation and enrich the theoretical guidance for logistics industry development in practice. Talent training solves the lack of talent in the new industry theoretically, but in practice, we should pay emphasis on the combination of practice and theory. From a more long-term development perspective, develop personnel training in depth to provide outstanding talent team for logistics development. In management and operation, we need to accumulate a certain amount of experience in practice. International trade development needs more comprehensive talents, who have certain insight on international trade insight and development, and form a complete knowledge system. This is the higher requirement for talents in logistics and economic development.

\section{Conclusion}

The development of coastal city logistics economy is leading the development of the whole country. At the same time of regional economic development, it has important influence on the development of international trade. The development of international trade has more complicated factors, and logistics economy as a fresh element is both an opportunity and a challenge to international trade development. In the process of economic globalization, the international trend of logistics industry is more and more obvious. China's open economic construction pattern has been a certain basis. In a more open environment, more exploration and innovation should be done to the logistics economy of coastal city. In the early development, mine more potential elements to promote the innovative development of logistics economy. The development of international trade is an important reflection of world economy development. In the development flow, regional economic development is deepening. The development vitality of coastal cities in China needs more supports. Driven by logistics economy, international trade stimulates regional economic development and international trade development is activated.

\section{References}

[1] Li Zheng. The relationship between China's coastal city logistics and economic development level and international trade research [J]. Logistics Technology, 2013, 21: 272-274.

[2] Lu Dan. The impact of Tianjin international logistics industry on international trade development [D]. Tianjin University of Technology, 2011.

[3] Ye Xiaogang. On regional differences of China's coastal port logistics development level [D]. China Ocean University, 2015.

[4] Tao Yi. The interaction development of port logistics and urban economic [D]. Dalian Maritime University, 2012. 